\title{
A generic model of forest canopy conductance dependent on climate, soil water availability and leaf area index
}

\author{
André Granier ${ }^{\mathrm{a}, *}$, Denis Loustau ${ }^{\mathrm{b}}$ and Nathalie Bréda ${ }^{\mathrm{a}}$ \\ ${ }^{a}$ Institut National de la Recherche Agronomique, Unité d'Écophysiologie Forestière, 54280 Champenoux, France \\ ${ }^{\mathrm{b}}$ Institut National de la Recherche Agronomique, Unité de Recherches Forestières, BP 45, 33611 Gazinet Cedex, France
}

(Received 2 June 2000; accepted 3 October 2000)

\begin{abstract}
This paper analyses the variation in tree canopy conductance for water vapour $\left(g_{c}\right)$ in order to derive a general expression, including the effects of solar radiation $(R)$, vapour pressure deficit $(D)$, leaf area index $(L A I)$ and extractable soil water. Canopy conductance was calculated from transpiration measured in 21 broadleaved and coniferous forest stands, under different climates: temperate, mountain, tropical and boreal. Common features in the dependence of $g_{\mathrm{c}}$ on climate and on soil water content were exhibited. When soil water was not limiting, $g_{c}$ was shown to increase linearly with $L A I$ in the range 0 to $6 \mathrm{~m}^{2} \mathrm{~m}^{-2}$ and reach a plateau value. Besides the positive effect of increasing $R$ and the negative effect of increasing $D$ on $g_{c}$, it was surprisingly shown that a decrease in extractable soil water induced a similar reduction in $g_{\mathrm{c}}$ in various tree species, equally in coniferous and in broadleaved. Based on these findings, a general canopy conductance function is proposed.
\end{abstract}

canopy conductance / sap flow / transpiration / species comparison / leaf area index / water stress / model / synthesis

Résumé - Un modèle générique de conductance de couverts forestiers dépendant du climat, de la disponibilité en eau dans le sol et de l'indice foliaire. Ce travail réalise l'analyse des facteurs de variation de la conductance du couvert pour la vapeur d'eau $\left(g_{c}\right)$ avec l'objectif d'en donner une expression générale, prenant en compte les effets du rayonnement global $(R)$, du déficit de saturation de l'air $(D)$, de l'indice foliaire $(L A I)$ et de la réserve hydrique extractible du sol. La conductance du couvert a été calculée à partir de la transpiration mesurée dans 21 peuplements forestiers feuillus et résineux, sous différents types climatiques : tempéré, montagnard, tropical et boréal. Ce travail a montré, pour ces divers peuplements, une dépendance similaire entre $g_{\mathrm{c}}$ et les facteurs climatiques, ainsi qu'avec la réserve hydrique extractible du sol $(R E W)$. En conditions hydriques non limitantes, on observe que $g_{c}$ augmente linéairement avec le $L A I$ entre 0 et $6 \mathrm{~m}^{2} \mathrm{~m}^{-2}$, puis atteint un plateau. De façon surprenante, en dehors de l'effet positif sur $g_{\mathrm{c}}$ de l'augmentation de $R$, et l'effet négatif de celle de $D$, on montre que la diminution de $R E W$ a des conséquences similaires sur $g_{c}$ pour diverses espèces forestières, aussi bien feuillues que résineuses. À partir de ces observations, un modèle général de conductance de couvert est proposé ici.

conductance de couvert / flux de sève / transpiration / comparaison inter spécifique / indice foliaire / sécheresse / modèle / synthèse

* Correspondence and reprints

Tél. (33) 03833940 38; Fax. (33) 03833940 69; e-mail: agranier@nancy.inra.fr 


\section{INTRODUCTION}

During the last decades, a large number of studies have been conducted, quantifying forest transpiration and its spatial and temporal variation, under various stand conditions (age, species, site, climate), involving different techniques. High time scale resolution (hour) data can be obtained through sap flow measurements [28], which have few requirements in term of fetch and stand topography as compared with the common meteorological methods. Sap flow has been shown to measure accurately stand transpiration $[9,10,28]$, providing an adequate sampling of sap flux accounting for variation in size, tree representativeness, species and age can be performed. Thus, sap flow is scaled most usually from individual trees to the stand, using a scaling variable, that can be tree circumference, sapwood area or leaf area [28].

When analysing stand transpiration, large temporal and spatial variation is generally observed. The first source of variation is due to climate because available energy and atmospheric deficit in vapour pressure drive the transpiration flux from vegetation to the atmosphere. The second source is the biological regulation exerted through canopy surface conductance, which is controlled mainly by stand $L A I$, and stomatal conductance. In addition, atmospheric turbulence and stand structure determines the aerodynamic transfer between the canopy and the atmosphere. However, it is widely recognized that the stand structure has a weak influence on variation in forest transpiration as compared to climatic factors and surface (or canopy) conductance. Forests are found over a wide range of climates and differ in many characteristics relevant to stand transpiration and canopy conductance, e.g. their phenology, leaf life span, drought response (avoidance vs. tolerance), canopy structure, etc. Whether some common pattern in canopy conductance emerge across forests is a challenging question since forest ecosystems must also satisfy common ecological constraints such as water conservation or xylem cavitation risk [49]. The aim was here to analyse the different sources of variation in canopy conductance between forest stands covering a wide range conditions, using a simple multivariate model, and try to separate the influence of climate from the intrinsic characteristics of stand.

Different approaches have been developed to model transpiration of forest stands. The most mechanistic models of canopy transpiration are multilayered [25]. They describe the canopy transpiration within horizontal elementary layers. The multilayered models must be used in the case of a two-layer vegetation as for instance to describe the functioning of an overstory-understory association [25]. Since the work of Jarvis and Mc Naughton (1976, [23]), many authors made the assumption that the whole canopy acts as a single layer for water exchange to the atmosphere, even if it has been demonstrated that multilayer models are more suitable for detailed physiological functioning of the forest canopy [39].

The objectives of this paper are to: 1) compare canopy conductance among a large range of forest stands, differing in species composition or in climatic and soil characteristics; 2) evaluate the effect of leaf area index as a possible source of variation in transpiration; 3) build a generic model of forest stand transpiration independent of tree species.

\section{METHODS}

\subsection{Sites}

Site characteristics and tree species used in the analysis are listed in table I. This data set covers a wide range of tree species, coniferous and broadleaved, under various climate and site conditions, temperate, tropical and boreal. In some stands, measurements were performed during several years, allowing us to take into account the inter-annual variation of climate (table I).

In some of these experiments, soil water content in the root zone was measured and data were converted to relative extractable water ( $R E W$, dimensionless), defined as:

$$
R E W=\frac{W-W_{\mathrm{m}}}{W_{\mathrm{FC}}-W_{\mathrm{m}}}
$$

where $W$ is the soil water content in the root zone, $W_{\mathrm{m}}$ is the minimum soil water (i.e. lower limit of water availability), $W_{\mathrm{FC}}$ is the soil water content at field capacity.

\subsection{Calculation of canopy conductance}

Canopy conductance for water vapour $\left(g_{c}, \mathrm{~m} \mathrm{~s}^{-1}\right)$ was calculated from transpiration measurements and from climate data using the rearranged Penman Monteith equation (see [18]):

$$
g_{\mathrm{c}}=\frac{g_{\mathrm{a}} E \lambda \gamma}{s A+\rho c_{\mathrm{p}} D g_{\mathrm{a}}-\lambda T(s+\gamma)}
$$

where $E\left(\mathrm{~kg} \mathrm{~m}^{-2} \mathrm{~s}^{-1}\right)$ is the stand transpiration, $\lambda\left(\mathrm{J} \mathrm{kg}^{-1}\right)$ is the latent heat of water vaporisation, $\gamma\left(\mathrm{Pa} \mathrm{K}^{-1}\right)$ is the psychometric constant, $s\left(\mathrm{~Pa} \mathrm{~K}^{-1}\right)$ is the rate of change of saturating vapour pressure with temperature, $A\left(\mathrm{~W} \mathrm{~m}^{-2}\right)$ is the available energy of the forest canopy, $\rho\left(\mathrm{kg} \mathrm{m}^{-3}\right)$ is the density of dry air, $c_{\mathrm{p}}\left(\mathrm{J} \mathrm{K}^{-1} \mathrm{~kg}^{-1}\right)$ is the specific heat of air, $D(\mathrm{~Pa})$ is the vapour pressure deficit, and $g_{\mathrm{a}}\left(\mathrm{m} \mathrm{s}^{-1}\right)$ is the 
Table I. Main characteristics of the sites. Methods used for fluxes measurements are sap flow (SF), eddy covariance (EC) or energy balance (EB).

\begin{tabular}{|c|c|c|c|c|c|c|c|c|}
\hline Species & Site & $\begin{array}{l}\text { Age } \\
(\mathrm{yr})\end{array}$ & $\begin{array}{l}\text { Height } \\
\text { (m) }\end{array}$ & $\begin{array}{l}\text { Temp } \\
\left({ }^{\circ} \mathrm{C}\right)\end{array}$ & $\begin{array}{l}\text { Rain } \\
(\mathrm{mm})\end{array}$ & $\begin{array}{l}\mathrm{LAI} \mathrm{m}^{2} \\
\qquad\left(\mathrm{~m}^{-2}\right)\end{array}$ & $\begin{array}{l}\text { Method } \\
\text { SF/EC }\end{array}$ & $\begin{array}{l}\text { Project / reference / } \\
\text { remarks }\end{array}$ \\
\hline Quercus petraea & Champenoux (France) & 35 & 15 & 9.6 & 740 & 6.0 & SF & control $[2,3]$ \\
\hline Q. petraea & Champenoux (France) & 35 & 15 & 9.6 & 740 & 3.3 & SF & thinned $[2,3]$ \\
\hline Q. rubra & Ede (The Netherlands) & & 17.4 & & & 4.9 & EB & {$[38]$} \\
\hline Fagus sylvatica & Hesse (France) & 30 & 14 & 9.2 & 820 & 5.7 & $\mathrm{SF} / \mathrm{EC}$ & EUROFLUX \\
\hline F. sylvatica & Aubure (France) & 120 & 22.5 & 6.0 & 1500 & 5.7 & SF & REKLIP \\
\hline F. sylvatica & Kiel (Germany) & 100 & 29 & 8.1 & 697 & 4.5 & EB & [19] \\
\hline Abies bornmulleriana & Champenoux (France) & 25 & 11 & 9.6 & 740 & 8.9 & SF & plantation \\
\hline Picea abies & Champenoux (France) & 21 & 11 & 9.6 & 740 & 9.5 & SF & plantation \\
\hline P. abies & Aubure (France) & 30 & 13 & 6.0 & 1500 & 6.1 & SF & REKLIP \\
\hline Pinus sylvestris & Hartheim (Germany) & 35 & 12 & 9.8 & 667 & 2.9 & $\mathrm{SF} / \mathrm{EC}$ & HartX [27] \\
\hline Pinus pinaster & Losse (France) & 37 & 20.3 & 13.5 & 900 & 2.5 & $\mathrm{SF} / \mathrm{EC}$ & HAPEX-MOBILHY [14] \\
\hline$P$. pinaster & Le Bray (France) & 18 & 12 & 13.5 & 900 & 2.7 & SF & EUROFLUX \\
\hline Tropical rainforest & Paracou (French Guiana) & & 33 & 25.8 & 2900 & 8.6 & SF & natural forest [16] \\
\hline Simarouba amara & Paracou (French Guiana) & 5 & 4.7 & 25.8 & 2900 & 3.5 & SF & plantation [17] \\
\hline Goupia glabra & Paracou (French Guiana) & 11 & 15 & 25.8 & 2900 & 4.3 & SF & plantation [16] \\
\hline Eperua falcata & Paracou (French Guiana) & 11 & 10 & 25.8 & 2900 & 10.8 & SF & plantation \\
\hline Pinus banksiana & Old Jack Pine (SA, Canada) & $75-90$ & 12.7 & 0.1 & 390 & 2.2 & $\mathrm{SF} / \mathrm{EC}$ & BOREAS [44] \\
\hline
\end{tabular}

aerodynamic conductance. We calculated $g_{\mathrm{a}}$ from Thom's [48] equation. In closed stands, available energy was assumed to be equal to the net radiation measured over the canopy, minus heat storage in the air and in the above ground biomass. In open stands (e.g. $L A I<3$ ), where a significant fraction of the radiative flux reaches the soil surface, heat flux in the soil should not be neglected. Nevertheless, in the absence of soil heat flux measurement in most of the studied stands, this term was not taken into account here. However, when $L A I<3.0$ and canopies did not occupy the entire ground area, canopies likely did not absorb all the net radiation and actual tree canopy conductance would be underestimated.

In some experiments, $E$ was directly measured above the stand (Bowen ratio or eddy covariance technique), while in other studies transpiration was estimated from sapflow measurements. In most of our experiments presented here, the continuous heating technique was used [8], performed on 5 to 10 trees according to stand heterogeneity [28]. For computing $g_{\mathrm{c}}$ from transpiration and climatic variables, some precautions were taken:

- periods during rainfall and for the 2 hours following rainfall were excluded in order to avoid the discrepancy between evaporation and tree transpiration,

- when either global radiation, vapour pressure deficit, or stand transpiration were too low $(<5 \%$ of the maximum value), data were also eliminated, because of the large relative uncertainties in computing $g_{c}$ from equation 2 under these conditions.
Typically, discarded data correspond to early morning and late afternoon periods. Furthermore, when $D$ is low during the early morning, dew is quite likely to occur and affects tree transpiration and its measurement.

Excluding these data has only limited consequences on calibrating the $g_{c}$ functions, because they represent periods of low transpiration rates. Modelling stand transpiration under conditions of maximum transpiration rates, i.e. when both $D$ and $g_{\mathrm{c}}$ are high (and therefore the product $g_{\mathrm{c}} \cdot D$ is high), is more crucial.

A time lag between sapflow and canopy transpiration has been often reported, even when the vapour flux above a stand was directly measured [11] or when it was estimated by a model $[5,15]$. This phenomenon is due to water exchanges between tissues and the transpiration stream within the trees [23]. This capacitance effect was often reported in coniferous species [18, 22, 30, 31, 45], the time lag being typically in the range of 1 to $2 \mathrm{~h}$, while it is much less important in broadleaved species $(30 \mathrm{~min}$ in oak, $60 \mathrm{~min}$ in poplar $[15,21])$. Water exchanges can be described with RC-analogue models [20, 31]. For an accurate calculation of canopy conductance, it is therefore necessary to take into account this time lag in order to improve the synchronism between sapflow and climatic demand. When this time lag is not taken into account, this would change the relationship between calculated $g_{c}$ and the climatic variables changes (e.g., figure 1). Furthermore, excluding the time lag results in an increase of the scatter of data: in this example, correlation coeffi- 




Figure 1. Effect of accounting for the time lag between sapflow and vapour pressure deficit $(D)$ on the estimate of canopy conductance in Pinus pinaster.

cients equalled to 0.32 with no time lag, vs. 0.67 with a $1 \mathrm{~h}$ time lag.

\subsection{The canopy conductance sub-model}

Jarvis and Steward [23, 47] proposed a multiplicativetype function to relate the variation of $g_{\mathrm{c}}$ to the environmental factors. This approach is now widely used $[6,7$, $12,15,18,38]$. The following model, derived from Jarvis and Steward [23, 47] was used here:

$$
g_{\mathrm{c}}=g_{\mathrm{cmax}} \cdot \mathrm{f}_{1}(R, D) \cdot \mathrm{f}_{2}(L A I) \cdot \mathrm{f}_{3}\left(I_{\mathrm{s}}\right) \cdot \mathrm{f}_{4}(t)
$$

where $g_{\text {cmax }}\left(\mathrm{m} \mathrm{s}^{-1}\right)$ is the maximum $g_{\mathrm{c}}$, reduced by the following functions $\mathrm{f}_{i}$ varying between 0 and 1 of: both global radiation $(R)$ and air vapour pressure deficit $(D)$ measured above the stand; leaf area index (LAI); a variable quantifying water stress intensity (Is); air temperature $(t)$. No interaction between the variables was assumed here. According to the studies, the variable used for water stress is either soil water deficit or leaf water potential (see Sect. 3.3 below).

Validation can be performed in several ways: parameterise canopy conductance function parameters from one year's data set, and compare estimated to measured $g_{\mathrm{c}}$ and transpiration for other years [47], compare model parameters obtained on even days to those on odd days within the same set of data [7], compare measured to computed stomatal conductances, derived from calculated canopy conductance and from $L A I$ [18].

In order to check if the response of one tree species could be extrapolated to other site and climate conditions, Granier et al. [13] compared measured tree transpiration in an old mountain beech forest (Aubure forest) to transpiration estimated from canopy conductance which was calibrated in another beech stand growing under plain conditions (Hesse forest, see table I).

Equation 3 was parameterised for each stand. First, coefficients of $\mathrm{f}_{1}(R, D)$ were fitted under non-limiting 
temperature and soil water, in stands with high $L A I(>6)$. Then, each other $\mathrm{f}_{i}$ function was separately parameterised.

In order to compare the stands, we calculated a standardised canopy conductance $\left(g_{c} *\right)$, corresponding to the following set of variables: global radiation $=500 \mathrm{~W} \mathrm{~m}^{-2}$, $D=1 \mathrm{kPa}$, Relative Extractable Water $=1$, and no limiting air temperature (i.e. in the range $18-30^{\circ} \mathrm{C}$ ).

\section{RESULTS}

\subsection{Effects of radiation, vpd and temperature}

An example of the variation of canopy conductance in beech (Fagus sylvatica) as a function of global radiation and vapour pressure deficit is shown in figure 2. As for stomatal conductance, canopy conductance increases when incident radiation increases, and decreases when vapour pressure deficit increases. We used Lohammartype equations for describing the combined effects of both variables, expressed as follow:

Model 1: $\quad g_{\mathrm{c}}=g_{\mathrm{cmax}} \frac{R}{R+R_{0}}(a-b \ln D)$
Model 2:

$$
g_{\mathrm{c}}=g_{\mathrm{cmax}} \frac{R}{R+R_{0}} \frac{1}{1+b \cdot D} .
$$

Fitting of the parameters in equations (4) and (5) (and in the further functions) was based on the minimum sum of squares using the Gauss-Marquardt algorithm. In contrast to stomatal conductance, those functions do not show a saturation at high values of $R$. The parameter $R_{0}$ varies according to the species between 50 and $300 \mathrm{~W} \mathrm{~m}^{-2}$, without any clear relation to leaf area index. Nevertheless, the highest $R_{0}$ coefficients are found in the coniferous stands.

Figure 2 shows a large scattering of $g_{c}$ within the lowest radiation class $\left(0\right.$ to $\left.200 \mathrm{~W} \mathrm{~m}^{-2}\right)$. This scatter is the result of both the rapid increase of $g_{\mathrm{c}}$ with $R$, but also to the large uncertainty in calculating canopy conductance at low values of transpiration, such as during early morning or late afternoon.

Parameterisation of $g_{c}$ needs to take into account, if possible, the effect of water exchange between tissues and sap flow, provoking a time lag between transpiration and sap flow. The procedure to test this capacitance effect was the following: we introduced increasing time lags $(0$, $0.5,1.0,1.5$ and $2.0 \mathrm{~h}$ ) in the calculation of $g_{c}$, sapflow lagging behind climatic variables. At each step, the function $f_{1}$ was fitted, and the regression coefficients were

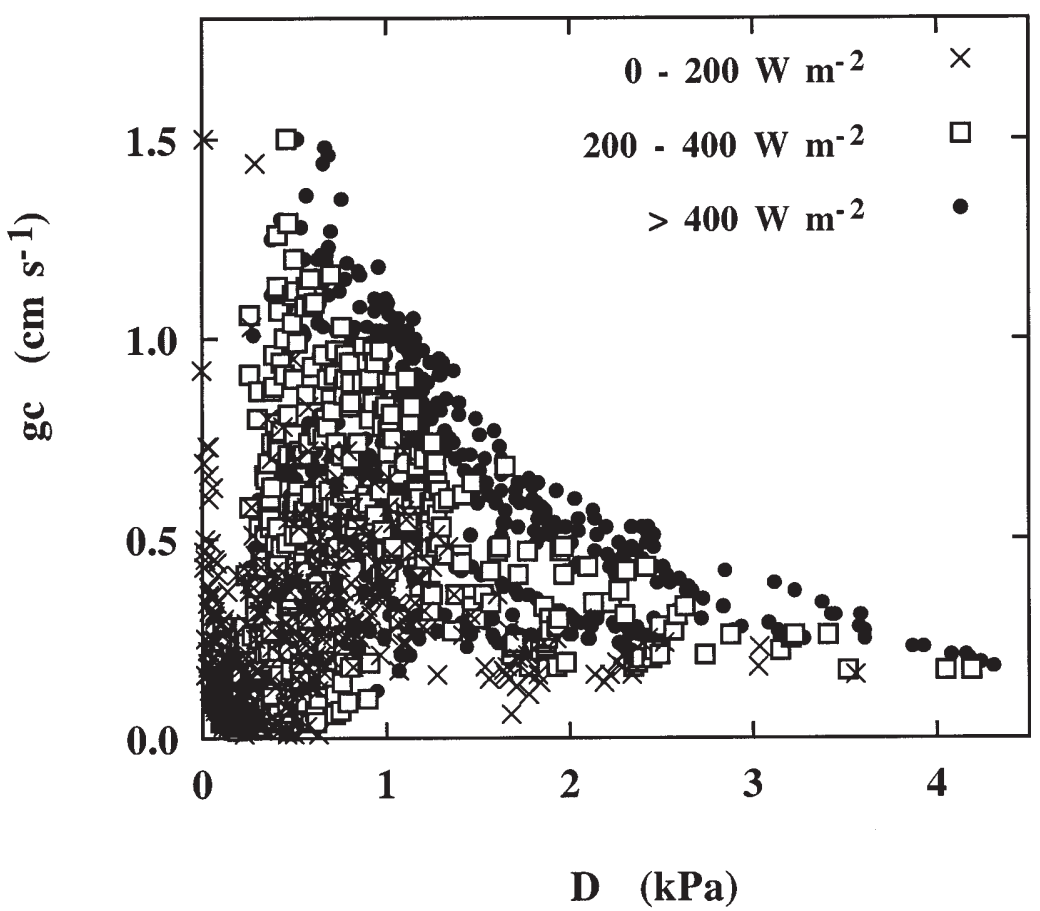

Figure 2. Canopy conductance $\left(g_{c}\right)$ in a beech forest (Fagus sylvatica) calculated from sapflow measurements as a function of vapour pressure deficit $(D)$. Data are sorted according to radiation. Euroflux experiment, Hesse forest 1998 (France). 
compared. The time lag was assumed to correspond to the highest $r^{2}$ obtained. We checked if this procedure was correct by comparing this estimated time lag to the observed time lag between water flux measured above the stand and scaled up sap flow in a Scots pine forest [11]; the same value was obtained, equal to $90 \mathrm{~min}$. For our sample species (table I), it varied between 0 and $1.5 \mathrm{~h}$, depending on tree species. We found that water stress increased the time lag in some tree species like Pinus pinaster or Picea abies (data not shown). In experiments where water supply varied during the season, we therefore applied this procedure to each soil water content class.

Because radiation and vapour pressure deficit are correlated ( $r^{2}$ ranging from 0.2 to 0.4 ), the coefficients $R_{0}, a$, and $b$ are also correlated.

The variation of canopy conductance vs. $D$, under high global radiation, $\mathrm{R}=700 \mathrm{~W} \mathrm{~m}^{-2}$ (figure 3 ), showed a similar pattern in all studied stands. The negative effect of increasing $D$ on $g_{c}$ was accurately modelled with functions 4 or 5 . Coefficients of determination for models 1 and 2 were in general close, but model 2 often gave slightly better fits than model 1 . Besides this common feature, some of the studied species were found to be more sensitive to $D$. Two examples are Quercus petraea, for both the control and thinned stands, and Simarouba amara (tropical). In other tree species (Abies bornmulleriana, temperate, and Eperua falcata, tropical), sensitivity of $g_{c}$ to $D$ was lower than the average response. According to the tree species, the relative variation of $g_{\mathrm{c}}$, when $D$ passed from 1 to $2 \mathrm{kPa}$, ranged from $-20 \%$ to $-60 \%$. As reported by Oren et al. [37], $g_{\text {c }}$ sensitivity to $D$ is well correlated with $g_{\text {cmax }}$. Fitting the coefficient $b$ to $a$ of equation (4) gave: $b=0.253 a\left(r^{2}=0.92\right.$, see insert of figure 3).

Absolute values of $g_{c}$ differed markedly among the stands. Canopy conductance appears to be higher in sites where $L A I$ is high (upper curves with closed symbols in figure 3, LAI being in the range of 5.7 to 10.8), than in low LAI stands.

When pooling all the stands where $L A I>5.7$, the following function was obtained:

$$
g_{\mathrm{c}}=4.047 \frac{R}{R+100} \frac{1}{1+2.0615 D} \quad\left(r^{2}=0.76\right)
$$

In most of the data sets that we used here, when the response of $g_{\mathrm{c}}$ to both $R$ and $D$ was extracted, no significant relationship between $g_{\mathrm{c}}$ residuals and air temperature was pointed out. This probably results from: i) the high correlation between air temperature and $D\left(r^{2}>0.5\right)$, ii) the narrow range of temperatures, because most of the observations were performed during summer.

\subsection{LAI}

Figure 4 shows the relationship between standardised canopy conductance $g_{\mathrm{c}}{ }^{*}$ and $L A I$ in 20 stands. For $L A I<$ $6, g_{c}{ }^{*}$ linearly increased to a value of $1.33 \mathrm{~cm} \mathrm{~s}^{-1}$. With LAI larger than 6.0, canopy conductance did not increased further.

The following function was fitted on this data set:

$$
\begin{array}{ll}
L A I \geq 6 & \mathrm{f}_{1}(L A I)=1 \\
L A I<6 & \mathrm{f}_{1}(L A I)=L A I / 6 .
\end{array}
$$

\subsection{Water stress}

Many studies have demonstrated the negative effect of soil water depletion on canopy conductance. Variation of $g_{c}$ can be related either to predawn water potential as in [32], to soil water reserve or soil water deficit [18], or to relative extractable water in the soil $(R E W)$ as in [15]. We preferred to use the latter variable for extensive studies and for modelling purposes, because:

- predawn water potential, even if it a physiological indicator of tree water status, and therefore has a more causal significance, is not often available in field studies;

- soil water reserve is very site dependent, ranging from ca. 50 to $200 \mathrm{~mm}$, according to rooting depth, soil properties, etc., while $R E W$ is varying between 0 and 1 , whatever the site;

- both predawn water potential and $R E W$ are strongly related [4].

Figure 5 illustrates the relationship between $g_{\mathrm{c}}$ and $R E W$ in five coniferous and broadleaved stands. For all these species, $g_{\mathrm{c}} / g_{\text {cmax }}$ progressively decreases when $R E W$ varies from 1 to 0 , this decrease being more pronounced when REW drops below 0.4 , as previously reported [12]. When pooling all the data, the following relationship was obtained:

$\mathrm{f}_{2}\left(I_{\mathrm{s}}\right)=\frac{p_{1}+p_{2} \cdot R E W-\left[\left(p_{1}+p_{2} \cdot R E W\right)^{2}-2.8 p_{1} \cdot p_{2} \cdot R E W\right]^{1 / 2}}{1.4}$

$\left(r^{2}=0.77\right)$

in which $p_{1}=1.154$ and $p_{2}=3.0195$. 

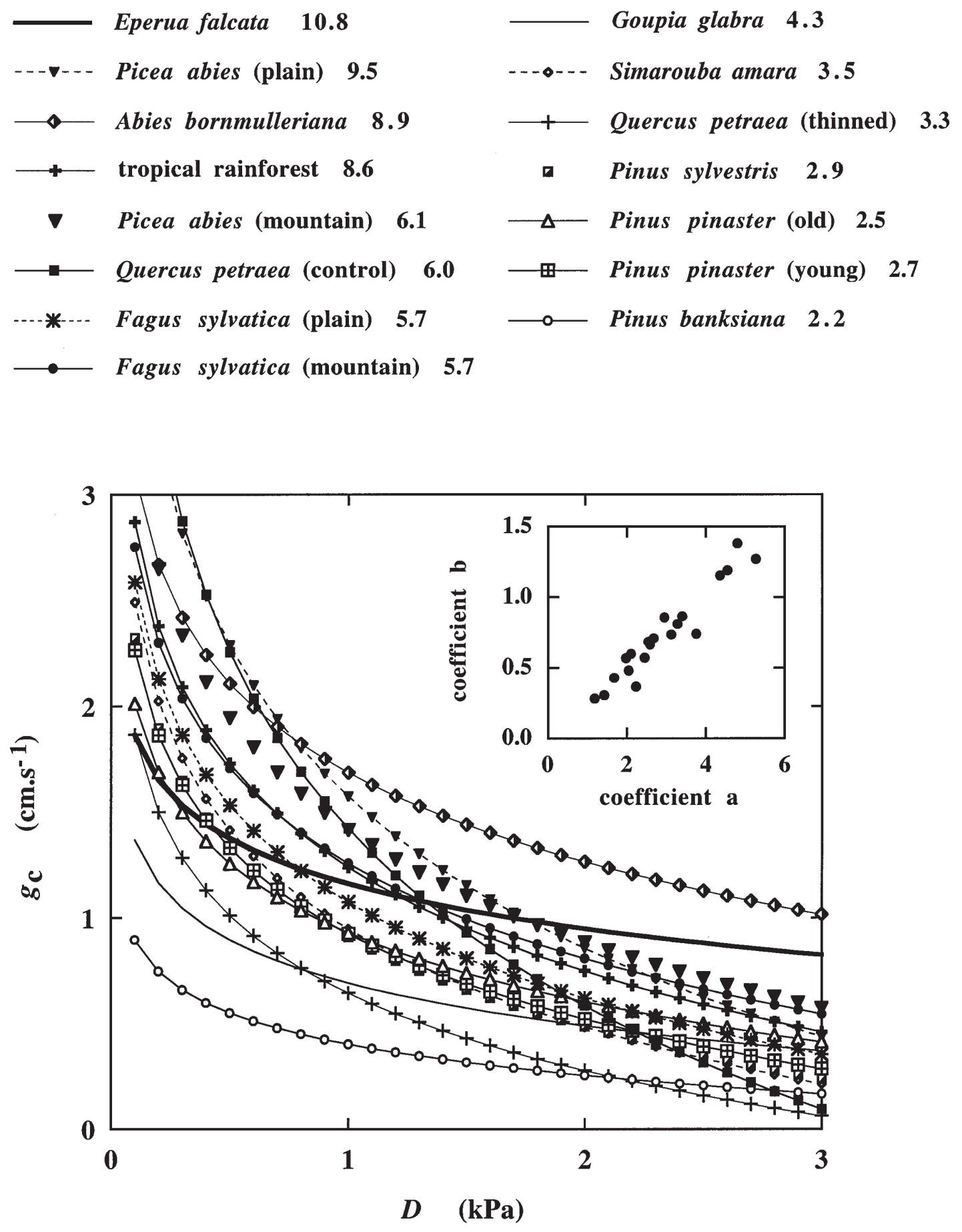

Figure 3. Canopy conductance of various forest stands as a function of vapour pressure deficit, for a global radiation of $700 \mathrm{~W} \mathrm{~m} \mathrm{~m}^{-2}$ under non-limiting soil water. Closed symbols correspond to stands with a high $L A I(\geq 5.7)$, open symbols or lines are for stands with a lower $L A I(<5.7)$. The value of $L A I$ is indicated in the legend. For Pinus pinaster + understorey: data of [7]. Insert, the relationship between the coefficients a and $\mathrm{b}$ of the model 3 (see text). 


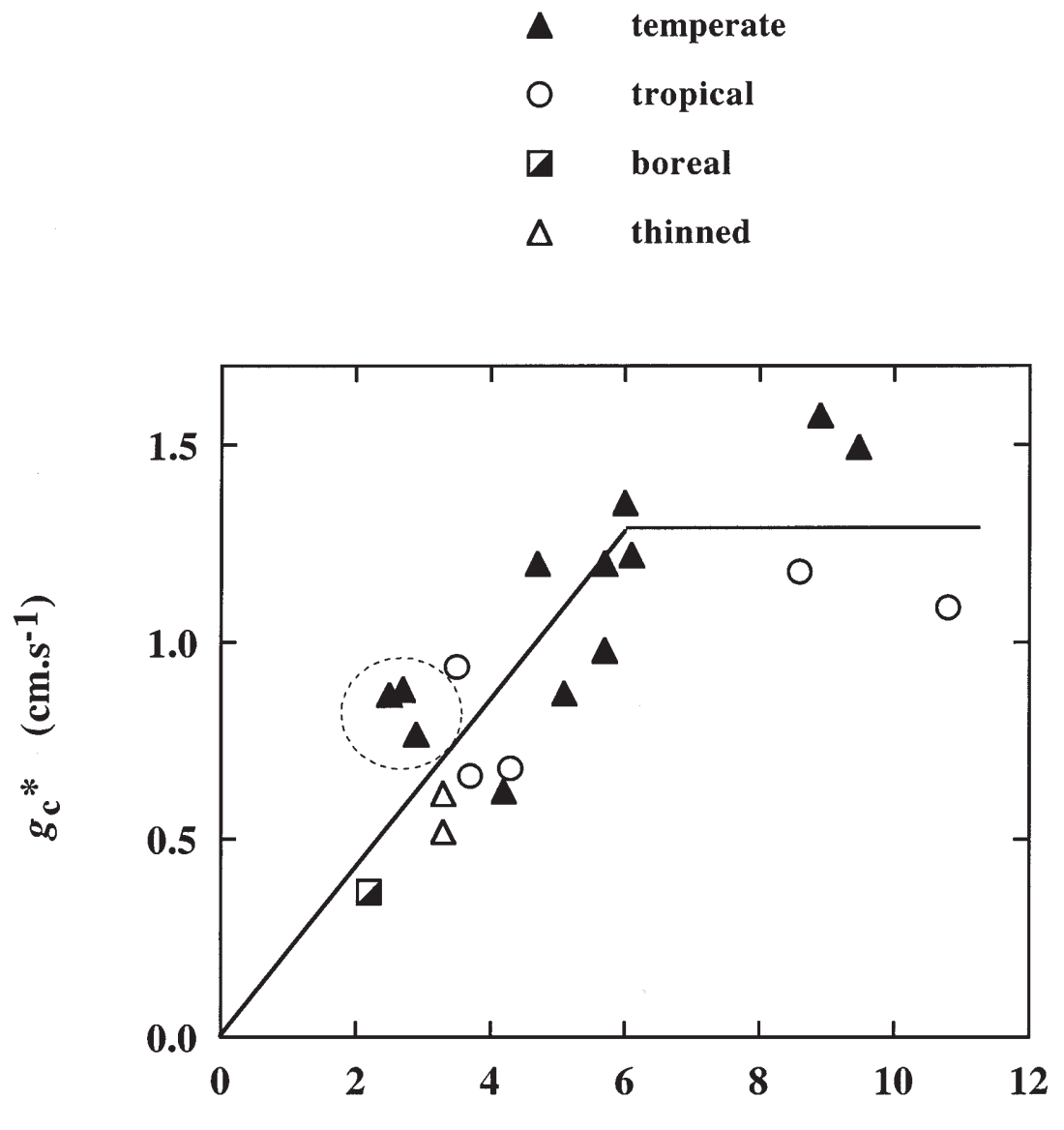

LA I
Figure 4. Standardised canopy conductance $g_{c}^{*}\left(R=500 \mathrm{~W} \mathrm{~m}^{-2}, D=1\right.$ $\mathrm{kPa}$ ) as a function of $L A I$ in 20 forest stands. Same data as for figure 3. Other values are coming from [19] and [38]. Data in the dotted circle are for the 3 pine stands (Pinus pinaster and $P$. sylvestris).

\section{DISCUSSION}

In contrast to grasslands, $g_{c}$ generally controls forest transpiration [26] because it is at least one order of magnitude lower than $g_{a}$. This is less true in poorly ventilated canopies such as in tropical rainforests $[34,40]$, in some dense deciduous plantations [21] or during early morning hours when windspeed (and therefore $g_{a}$ ) is still low [33]. In most of the studies we reported here, the decoupling coefficient $\Omega$, as defined by McNaughton and Jarvis [36], ranged between 0.1 and 0.2 , demonstrating a strong coupling between the canopies and the atmosphere. Thus, the simplified model of transpiration proposed by McNaughton and Black [35], derived from the PenmanMonteith equation, is applicable in most forest types. In this simplified model, transpiration is proportional to $D$, $g_{\mathrm{c}}$ and $L A I$.

The dependence of $g_{\mathrm{c}}$ on $D$, expressed as the slope of $g_{\text {c }}$ vs. $\ln (D)$ (= coefficient $b$ of equation (4)), relative to the intercept (= coefficient $a$ ) was found to be similar between the forest stands reported here. A few exceptions were noted. Two species demonstrated a slightly higher sensitivity to atmospheric drought i.e. Quercus petraea and Simarouba amara, two light demanding tree species. Finally, two species showed lower sensitivity, i.e. Abies bornmulleriana and Eperua falcata, both shade tolerant and high LAI species. The common response of $g_{\mathrm{c}}$ to $D$ (in 13 of the 17 species in table I) contrasts strongly with leaf level measurements of stomatal conductance. Larger differential stomatal sensitivity between species to air vapour pressure deficit has been often reported, among conifer species (e.g. in Sandford and Jarvis [42]). Our observation probably results from the averaged response of a whole canopy, resulting from the mixing of leaves of different physiological properties (sun vs. shade, leaves of different ages in coniferous species, etc.), submitted to differing environmental conditions [29]. 


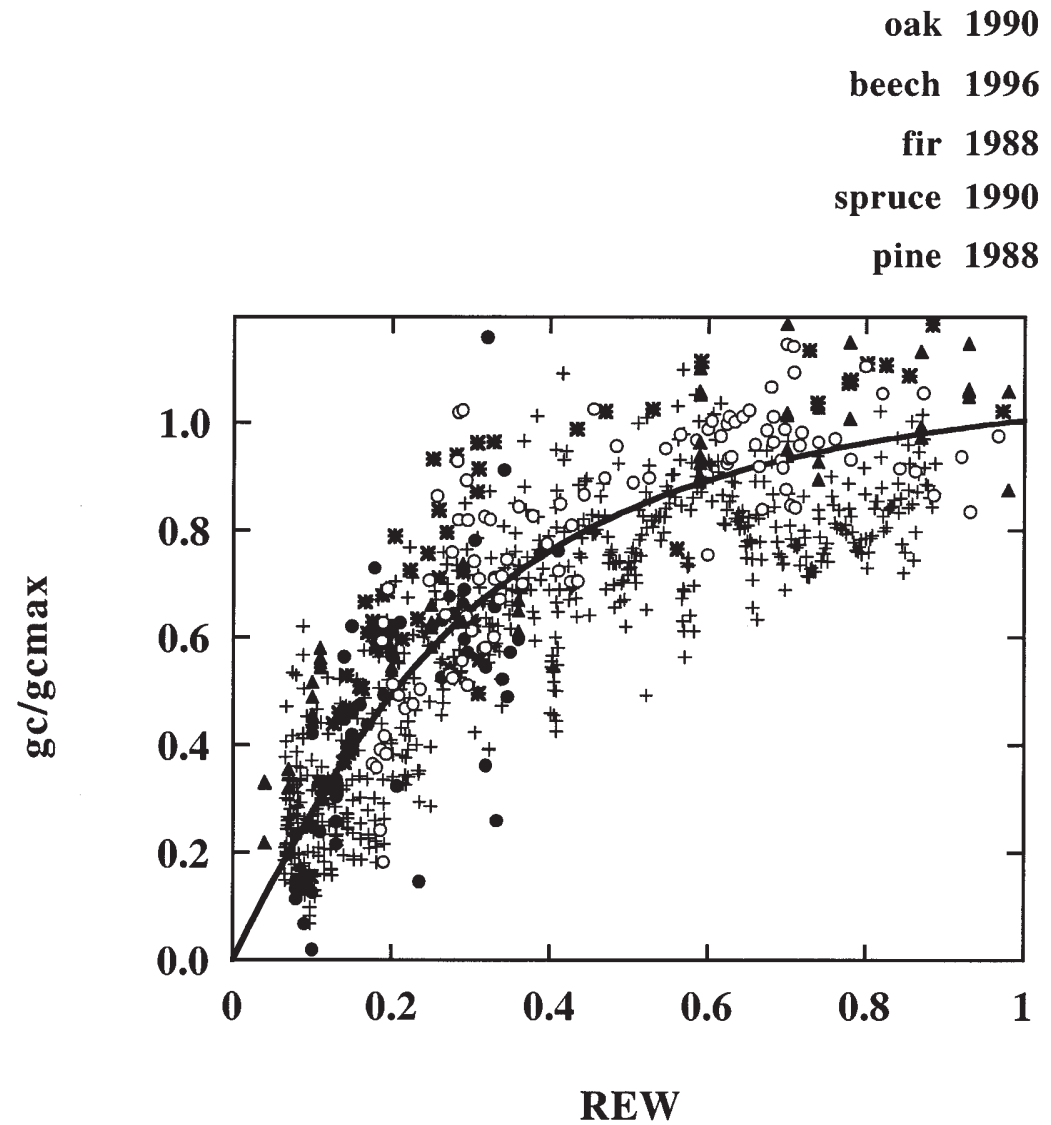

Figure 5. Variation of relative canopy conductance $\left(g_{\mathrm{c}} / g_{\mathrm{cmax}}\right)$, as a function of relative extractable water in the soil $(R E W)$ in 5 forest stands: oak (Quercus petraea, $L A I=6.0)$, beech (Fagus sylvatica, $L A I=5.8$ ), fir (Abies bornmulleriana, $L A I=8.9)$, spruce (Picea abies, $L A I=6.1$ ) and pine (Pinus pinaster, $L A I=2.7$ ). In oak, beech, spruce and pine, $g_{\mathrm{c}}$ is related to modelled $g_{\text {cmax }}$. In fir, $g_{c}$ is related to $g_{\text {cmax }}$ measured in a well-watered plot. A unique relationship was drawn.

The effect of air temperature on $g_{c}$, although being less investigated, seems to play an important role in the regulation of stomatal and hence canopy conductance. In Scots pine, Gash et al. [7] calibrated a parabolic function with an optimum between 15 and $20^{\circ} \mathrm{C}$. In beech, Granier et al. [13] found in spring a decrease in $g_{c}$ when air temperature dropped below $15^{\circ} \mathrm{C}$. On the opposite, no temperature effect was detected for oaks, neither in spring nor in summer. Our attempts to derive the function $\mathrm{f}_{3}$ in equation (3) were not successful, and there are not enough data yet available to derive a general relationship. Probably, different species could show a different sensitivity to temperature and different optima, tropical species probably being more sensitive to temperature than temperate and boreal species. Furthermore, Gash et al. [7] calibrated different functions relating the dependence of $g_{\mathrm{c}}$ to temperature in a same tree species (Pinus pinaster) growing in two sites.

A close similarity in transpiration of different forests was also reported by Granier et al. [13] in two beech stands, differing in both age (30 vs. 120 years old), and growing conditions (plain vs. mountain). Moreover, in this work, a comparison with the data from Herbst [19] on the same species also showed very close $g_{c}$ function. These 3 stands were characterised by similar values of LAI (5.5 to 6.0).

Canopy conductance is nearly proportional to $L A I$ between 0 to 6 , as previously shown by Granier and Bréda [15], in which different temperate oak stands were compared. Similar results have been noted within the same stand during leaf expansion [15]. Compared to forests, low vegetation like crops and grasslands, exhibit a different response to increasing $L A I$, with $g_{c}$ and transpiration saturating at a much lower $L A I$ threshold (about 3 to 4) [43]. The saturation of forest transpiration at $L A I$ higher than 6.0 can be explained by the important shading of low canopy strata by the upper levels when $L A I$ increases. For $L A I$ s less than 6, leaf area index is therefore a key factor for explaining between-stand variation in transpiration. Nevertheless, two tree species, Pinus pinaster and P. Sylvestris (figure 4, dotted circle), were distinguished from the average $g_{\mathrm{c}}{ }^{*}(L A I)$ relationship, 
probably due to their clumped crown structure and, therefore, to their different radiation absorbing properties. Similarity in response of various forest types to climate has been previously highlighted by Shuttleworth [46] who compared time courses of canopy conductance of various temperate and tropical forests (see his figure 10, p. 146). He found an average value of $1 \mathrm{~cm} \mathrm{~s}^{-1}$ for most species. Under similar high radiation conditions, this corresponds to the value of $g_{\mathrm{c}}$ that was observed here when $D$ equals about $1.5 \mathrm{kPa}$ in forest stands with high $L A I$ $(\geq 6)$.

The effect of soil water deficit on $g_{c}$ was rather surprising. A very similar response was noted in five very different species (figure 5). For instance, Pinus pinaster is a drought avoider [1], whereas Quercus petraea is a drought tolerater [2]. The threshold 0.4 for $R E W$, beyond which canopy conductance is linearly reduced, was previously reported in a large spectrum of tree species and soil types [12].

In conclusion, this work demonstrated that a generic model of canopy conductance could be proposed, as much for broadleaved as coniferous forest stands, even if physiological differences are often observed at the leaf level. This probably results from the canopy approach that buffers the response of individual leaves forming the canopy. For instance in the Amazonian forest, the canopy layers behave differentially [40, 41], the lower layers being less ventilated and therefore less coupled to the atmosphere than the upper levels. Nevertheless, the whole canopy response to both $R$ and $D$ is not very different from that of any other canopies [46].

We also showed that tree transpiration in open stands is reduced when decreasing LAI. Nevertheless, the total evapotranspiration is not proportionally reduced, since stand opening increases the available energy reaching the understorey vegetation and therefore increases its transpiration rate.

\section{REFERENCES}

[1] Aussenac G., Granier A., Quelques résultats de cinétique journalière du potentiel de sève chez les arbres forestiers, Ann. Sci. For. 35 (1978) 19-32.

[2] Bréda N., Cochard H., Dreyer E., Granier A., Water transfer in a mature oak stand (Quercus petraea): seasonal evolution and effects of a severe drought, Can. J. For. Res. 23 (1993) 1136-1143.

[3] Bréda N., Cochard H., Dreyer E., Granier A., Field comparison of transpiration, stomatal conductance and vulnerability to cavitation of Quercus petraea and Quercus robur under water stress, Ann. Sci. For. 50 (1993) 571-582.
[4] Bréda N., Granier A., Barataud F., Moyne C., Soil water dynamics in an oak stand. I. Soil moisture, water potentials and water uptake by roots, Plant and Soil 172 (1995) 17-27.

[5] Cienciala E., Lindroth A., Cermak J., Hallgren J.E., Kucera J., Assessment of transpiration estimates for Picea abies trees during a growing season, Trees - Structure and Function 6 (1992) 121-127.

[6] Dolman A.J., van Den Burg G.J., Stomatal behaviour in an oak canopy, Agric. For. Meteorol. 43 (1988) 99-108.

[7] Gash J.H.C., Shuttleworth W.J., Lloyd C.R., André J.C., Goutorbe J.P., Gelpe J., Micrometeorological measurements in Les Landes forest during HAPEX-MOBILHY, Agric. For. Meteorol. 43 (1989) 131-147.

[8] Granier A., Une nouvelle méthode pour la mesure du flux de sève brute dans le tronc des arbres, Ann. Sci. For. 42 (1985) 193-200.

[9] Granier A., Evaluation of transpiration in a Douglas-fir stand by means of sap flow measurements, Tree Physiol. 3 (1987) 309-320.

[10] Granier A., Biron P., Bréda N., Pontailler J.-Y., Saugier B., Transpiration of trees and forest stands: short and long-term monitoring using sapflow methods, Global Change Biology (1996) 265-274.

[11] Granier A., Biron P., Köstner B., Gay L.W., Najjar G., Comparisons of xylem sap flow and water vapour flux at the stand level and derivation of canopy conductance for Scots pine, Theor. Appl. Climat. 53 (1996) 115-122.

[12] Granier A., Bréda N., Biron, P., Villette S., A lumped water balance model to evaluate duration and intensity of drought constraints in forest stands, Ecol. Modelling 116 (1999) 269-283.

[13] Granier A., Biron P., Lemoine D., Water balance, transpiration and canopy conductance in two beech stands, Agric. For. Meteorol. 100 (2000) 291-308.

[14] Granier A., Bobay V., Gash J.H.C., Gelpe J., Saugier B., Shuttleworth W.J., Vapour flux density and transpiration rate comparisons in a stand of Maritime Pine (Pinus pinaster Ait.) in Les Landes forest, Agric. For. Meteorol. 51 (1990) 309-319.

[15] Granier A., Bréda N., Modelling canopy conductance and stand transpiration of an oak forest from sap flow measurements, Ann. Sci. For. 53 (1996) 537-546.

[16] Granier A., Huc R., Barigah S.T., Transpiration of natural rain forest and its dependence on climatic factors, Agric. For. Meteorol. 78 (1996) 19-29.

[17] Granier A., Huc R., Colin F., Transpiration and stomatal conductance of two rain forest species growing in plantations (Simarouba amara and Goupia glabra) in French Guyana, Ann. Sci. For. 49 (1992) 17-24

[18] Granier A., Loustau D., Measuring and modelling the transpiration of a maritime pine canopy from sap-flow data, Agric. For. Meteorol. 71 (1994) 61-81.

[19] Herbst M., Stomatal behaviour in a beech canopy: An analysis of Bowen ratio measurements compared with porometer data, Plant Cell Environ. 18 (1995) 1010-1018.

[20] Herzog K.M., Häsler R., Thum R., Diurnal changes in the radius of a subalpine Norway spruce stem: their relation to 
the sap flow and their use to estimate transpiration, Trees Structure and Function, 10 (1995) 94-101.

[21] Hinckley T.M., Brooks J.R., Cermark J., Ceulemans R., Kucera J., Meinzer F.C., Roberts D.A., Water flux in a hybrid poplar stand, Tree Physiol. 14 (1994) 1005-1018.

[22] Jarvis P.G., Water Transfer in Plants, in: de Vries D.A. and Afgan N.G. (Eds.), Heat and Mass Transfer in the Plant Environment, Part 1, Scripta Book Co., Washington D.C., 1975, pp. 369-374.

[23] Jarvis P.G., The interpretation of the variations in leaf water potential and stomatal conductance found in canopies in the field. Phil. Trans. R. Soc. Lond. ser. B 273 (1976) 593-610.

[24] Jarvis P.G., McNaughton K.G., Stomatal control of transpiration: scaling up from leaf to region. Advances in ecological Research, Academic Press, London 15 (1986) 1-49.

[25] Kelliher F.M., Black T.A., Price D.T., Estimating the effects of undestory removal from a Douglas-fir forest using a two-layer canopy evapotranspiration model, Water Resour. Res. 22 (1986) 1891-99.

[26] Kelliher F.M., Leuning, R., Schulze, E.D Evaporation and canopy characteristics of coniferous forests and grasslands - Review, Oecologia 95 (1993) 153-163.

[27] Köstner B., Biron P., Siegwolf R., Granier A Estimates of water vapor flux and canopy conductance of Scots pine at the tree level utilizing different xylem sap flow methods, Theor. Appl. Climat. 53 (1996) 105-113.

[28] Köstner B., Granier A., Cermák J., Sap flow measurements in forest stands - methods and uncertainties, Ann. Sci. For. 55 (1998) 13-27.

[29] Leverenz J.W., Deans J.D, Ford E.D., Jarvis P.G., Milne R., Whitehead D., Systematic spatial variation of stomatal conductance in a Sitka spruce plantation, J. Appl. Ecol. 19 (1982) 835-851.

[30] Loustau D., Berbigier P., Roumagnac P., Ferreira M.I., Pereira J.S., Arruda-Pacheco C., David J.S., Tavares R., Transpiration of a 64-year-old maritime pine stand in Portugal. I: Seasonal course of water flux through maritime pine. Oecologia 107 (1996) 33-42

[31] Loustau D., Domec J.C., Bosc A., Interpreting the variation in xylem sap flux density within the trunk of maritime pine (Pinus pinaster Ait.): application of a model for calculating water flows at tree and stand levels, Ann. Sci. For. 55 (1998) $29-46$.

[32] Lu P., Bréda N., Biron P., Granier A., Water relations of adult Norway spruce trees under soil drought in the Vosges montains: water potential, stomatal conductance and transpiration, Ann. Sci. For. 52 (1995) 117-129.

[33] Martin T.A., Brown K.J., Hinckley T.M., Kucera J., Meinzer F.C., Sprugel D.G., Control of transpiration in a 220year-old Abies amabilis forest, For. Ecol. Manage (in press).

[34] Meinzer F.C., Goldstein G., Holbrook N.M., Jackson P., Cavelier J., Stomatal and environmental control of transpiration in a lowland tropical forest tree, Plant Cell Environ. 16 (1993) 428-436.

[35] Naughton K.G., Black T.A., Evapotranspiration from a forest: A micrometeorological study, Water Resour. Res. 9 (1973) 1579-1590.

[36] Naughton K.G., Jarvis P.G., Predicting the effects of vegetation changes on transpiration and evaporation, in: Kozlowski T.T (Ed.), Water deficits and plant growth, Vol. VII, Academic Press, New York, 1983, pp. 1-47.

[37] Oren R., Sperry J.S., Katul G.G., Pataki D.E., Ewers B.E., Phillips N., Schäfer K.V.R., Survey and synthesis of intraand interspecific variation in stomatal sensitivity to vapour pressure deficit, Plant Cell Environ. 22 (1999) 1515-1526.

[38] Ogink-Hendriks M.J., Modelling surface conductance and transpiration of an oak forest in the Netherlands, Agric. For. Meteorol. 74 (1995) 99-118.

[39] Raupach M.R., Finnigan J.J., "Single layer models of evaporation from plant canopies are incorrect but useful, whereas multilayer models are correct but useless": discuss. Aust. J. Plant Physiol. 15 (1988) 705-16.

[40] Roberts J., Cabral O.M.R, Aguiar L. de F., Stomatal and boundary-layer conductances in Amazonian terra firme rain forest, J. Appl. Ecol. 27 (1990) 336-353.

[41] Roberts J., Cabral O.M.R., Fisch G., Molion L.C.B, Moore C.J., Shuttleworth W.J., Transpiration from an Amazonian rainforest calculated from stomatal conductance measurements, Agric. For. Meteorol. 65 (1993) 175-196.

[42] Sandford A.P., Jarvis P.G., Stomatal responses to humidity in selected conifers, Tree Physiol. 2 (1986) 89-103.

[43] Saugier B., The evapotranspiration of grasslands and crops, C. R. Acad. Agric. Fr. 82 (1996) 133-153.

[44] Saugier B., Granier A., Pontailler J.-Y., Dufrêne E., Baldocchi D.D., Transpiration of a boreal pine forest measured by branch bags, sapflow and micrometeorological methods, Tree Physiol. 17 (1996) 511-519.

[45] Schulze E.D., Cermak J., Matyssek R., Penka M., Zimmermann R., Vasicek F., Gries W., Kucera J., Canopy transpiration and water fluxes in the xylem of the trunk of Larix and Picea trees: a comparison of xylem flow, porometer and cuvette measurements, Oecologia 66 (1985) 475-483.

[46] Shuttleworth W.J., Micrometeorology of temperate and tropical forest, Phil. Trans. R. Soc. Lond., ser. B 324 (1989) 299-334.

[47] Stewart J.B., Modelling surface conductance of pine forest, Agric. For. Meteorol. 43 (1988) 19-35.

[48] Thom A.S., Momentum, mass and heat exchange of plant communities, in: Monteith J.L. (Ed.), Vegetation and the atmosphere, Vol. 1, Academic Press, London, 1975.

[49] Whitehead D., Regulation of stomatal conductance and transpiration in forest canopies, Tree Physiol. 18 (1998) 633-644. 